Title: The Limits of Liability: Anglo-American Organisations and Vicarious Liability from the $19^{\text {th }}$ Century to the Present

Author(s): Jacob Joad

Source: St Andrews Law Journal, 1:1 (November 2020), 5-15

Published by: Institute of Legal and Constitutional Research, University of St Andrews

DOI: https://doi.org/10.15664/stalj.v1i1.2342

This work is protected under Creative Commons Attribution 4.0 International (CC BY 4.0) License 2021.

The Author(s) retain copyright holding, having permitted the St Andrews Law Journal to distribute (publish) their work. All written content, Copyright @ the Author(s)

The St Andrews Law Journal is an Open Access publication of the University of St Andrews, published by the Institute of Legal and Constitutional Research with support from the University of St Andrews Journal Hosting Service 


\section{The Limits of Liability: Anglo-American Organisations and Vicarious Liability from the 19th Century to the Present}

By Jacob Joad

|Preamble|

| This paper, 'Limits of Liability', shall focus on the recent history of the concept of vicarious liability in Anglo-American common law from the 19th century to the present. |

Vicarious liability - often called respondeat superior in the United States concerns holding employers ('masters') liable for torts committed by their employees ('servants'), even when the employer is not at fault. In AngloAmerican common law, it has been a principle for over 150 years. ${ }^{1}$ There are references to the doctrine in cases dating back to the Middle Ages, but vicarious liability primarily evolved into its modern form in the nineteenth century. Such a development was driven by the necessities of the industrial age, with increasing technological and commercial development creating a more 'fertile' environment for claims involving the doctrine. ${ }^{2}$ As time has worn on and businesses have become larger, however, vicarious liability has been applied in cases where the employee-employer relationship has been increasingly distant and the tort committed increasingly contrary to the tortfeasor's 'scope of employment'. Subsequently, organisations in England and the United States at present must be increasingly weary of their employees or 'servants'. This paper will first give a historical overview of the development of vicarious liability before analysing the reasons in case law which have led to this situation in Anglo-American law, drawing upon twentieth-century legal scholarship from both sides of the Atlantic which plotted and commentated on the increasingly liberal application of vicarious liability. The paper will then view three common justifications for vicarious liability, which lend to the reasoning for the development of the doctrine. Finally, the paper will look at

${ }^{1}$ Green, Respondeat Superior

2 Gilker, Vicarious Liability in Tort, 6-8. 
very recent legislation, viewing possible issues for the doctrine in the near future.

The traceable development of vicarious liability in common law in England and the United States of America stretches back to the early to mid-nineteenth century. It was then when the basic principles were laid down as guidance for the application of vicarious liability. In the United States, Wright $v$ Wilcox (1838) 19 Wend. (N.Y.) 343 established the principle that malicious intent by the servant in the course of employment removes the master's vicarious liability for the actions of their servant. 3 The court in that case also established the idea that a master is only responsible if it can be proved that the master assented to the servant's carrying out the tort.4 In England, Joel $v$ Morison (1834) established that the master was not vicariously liable if the servant acted "on a frolic of his own." 5 Essentially, England and the United States founded the doctrine on a similar 'test' - that is, the establishment of whether the servant was acting in the interest of their master or in the interest of themselves. Such a simple test received an initial, but mostly terminological, development in England in the 1860s, following cases including Limpus $v$ London General Omnibus Co (1862), where "scope of employment" replaced "course of employment" (the latter used in Joel v Morrison) to ascertain whether assent from the master to the servant for their tort was implicitly given by being in the interest of the task(s) the servant was employed to do. "Scope of employment" has since been a basis for determining the application of vicarious liability in English common law to the present. In America, malicious intent as an exemption from vicarious liability was overturned as a legal distinction soon after Wright $v$ Wilcox, but malice was still considered when determining vicarious liability in courts.7 Around the turn of the twentieth century, another distinction emerged affecting the application of vicarious liability in both England and America. Allan W. Leiser pointed out in 1956 that vicarious liability was applied more reluctantly in the United States when the

${ }^{3}$ Master and Servant, 186

${ }^{4}$ Brill, The Liability of an Employer, 4.

5 (1834) 6 C \& P 501.

${ }^{6}$ (1862) 1 H \& C 526.

7 Master and Servant, 186. 
servant had committed a wilful act, rather than a negligent one. The Michigan and Texas courts, in cases in 1911 and 1891 respectively, reasoned that wilful acts were less predictable than negligent ones and, as such, fall outside the scope of employment. ${ }^{8}$ A different distinction emerged in English law. In Lloyd $v$ Grace, Smith \& Co (1912), no distinction between wilful and negligent acts was added. Instead, overturning the old precedent that, in the words of Willes $\mathrm{J}$, the act must be "for the master's benefit", the House of Lords deemed that the fraudulent acts of a managing clerk in a solicitor's firm did not have to benefit the firm in order to hold the firm vicariously liable. ${ }^{9}$ As such, the idea that vicarious liability should only be applied to cases where the master benefitted from the tort was removed from the law.

By the mid-twentieth century the exemption of wilful acts from vicarious liability was overturned in the United States, giving way to a definition similar to that in English common law. The wilfulness exemption to the doctrine was overturned in a Virginia case (among others) in 1948, where it was deemed that the master was vicariously liable if the wilful act was committed in the interest of the master's business. A more radical 'liberalisation' of the doctrine emerged in a 1955 Georgia court case, which saw the distinction move between determining whether the servant had willingly stepped out of his employment, to whether the servant's act was sufficiently close in connection to their employment to hold the master vicariously liable for it. ${ }^{10}$

This 'close connection test' has been the emphasis of vicarious liability cases in England since the end of the twentieth century. The change has shifted the paradigm of vicarious liability further away from the nineteenth century 'wilful' and 'master's benefit' considerations. Lister $v$ Hesley Hall Ltd (2001) was a mark of this change. In this case, the warden of a boarding annex of a school was found guilty of sexually abusing the boys in the annex. A Court of Appeal decision rejected the initial claim of vicarious liability against Hesley Hall Ltd, but an appeal in the House of Lords found Hesley Hall Ltd vicariously liable for the sexual abuse of the boys by the warden, despite acting clearly

${ }^{8}$ Leiser, Respondeat Superior, 338-339.

9 [1912] UKHL 606.

${ }_{10}$ Leiser, Respondeat Superior, 340 
outside the 'scope of employment'. ${ }^{11}$ The doctrine of vicarious liability evolved in two ways in this case. Lister set the precedent that masters could be found vicariously liable for sexual abuse by servants and the opportunity to commit a tort - derived from the authority provided by their position as a servant could lead to claims of the doctrine against employers. It must be noted that Lord Millett did draw upon the Australian case Deatons Pty Ltd $v$ Flew (1949) 79 CLR 370 to distinguish how the 'opportunity' component is negated when a supervisor to the tortious servant is present when the tort is committed.12 Nevertheless, Lister $v$ Hesley Hall created a precedent which left vicarious liability open to further expansion. Indeed, more recent cases and appeals in English courts, such as The Catholic Child Welfare Society $v$ Various Claimants and the Institute of the Brothers of the Christian Schools and others (2012) ${ }^{13}$ has demonstrated the result of this expansion. In this case (also called the 'Christian Brothers' case), the Institute of Brothers of Christian Schools was found vicariously liable for the sexual abuse of boys by the volunteers in the Institute (the 'brothers'), given the fact that the servants had been placed in relationships by the boys where there was a "significantly enhanced risk" of sexual abuse. ${ }^{14}$

Recent editions of legal reviews in the United States have highlighted a marked rigidity - compared to the English courts at least - in the application of the doctrine regarding sexual misconduct (the central issue of the 'Christian Brothers' case). Since the 1980 os, courts in states including Georgia and Connecticut have dismissed vicarious liability claims involving intentional sexual misconduct by the servants. ${ }^{15}$ The Californian courts in Lisa M v. Henry Mayo Newhall regarded "opportunity" to commit a tort alone insufficient for vicarious liability to hold; rather, an "emotional involvement" between the tortfeasor and victim and authority deemed as "coercive" are necessary for the doctrine to hold on the grounds of the 'scope of employment' angle.16 Regarding religious 'masters', a doctrine has been established in the United

11 [2001] UKHL 22.

12 [2001] UKHL 22, para 81.

13 [2012] UKSC 56.

14 [2012] UKHL 56, para 85-87.

${ }^{15}$ Hornbeck, Four Approaches, 993-994.

${ }^{16}$ Sartor, The Implications of Fearing v. Bucher, 712. 
States some call "church autonomy", whereby religious employers are treated (in a general sense) as not being liable for the torts of their servants. This doctrine is particularly pronounced with denominations like the Catholic Church, where sexual abuse by 'servants' is specifically forbidden. Some have questioned this doctrine, particularly since the aforementioned 'coercive authority' idea is very much applicable with many sexual abuse cases in the Catholic Church. ${ }^{17}$

As such, 'opportunity' to commit a tort, derived from the authority invested in a servant by the master, has become an important part of Anglo-American common law decisions on vicarious liability. The 'church autonomy' idea in American common law puts vicarious liability under greater constraints than in English common law. Are these constraints necessary? Just because the Catholic Church specifically forbids sexual assault should not mean that vicarious liability should be treated differently. The secular laws of both England and the United States explicitly forbid sexual assault, so why should a Church authority be any different? Later in the paper, a significant American case challenging this unusual exemption will be discussed. Before discussion of very recent legislation, an assessment of the various rationales for the doctrine of vicarious liability in Anglo-American common law should be made to fully understand why it exists in the expanded state it does today. Theories for the expansion of the doctrine are grounded in the fundamental idea that vicarious liability is ultimately a matter of public policy. Paragraph 40 of Mohamud $v$ WM Morrison Supermarkets Plc (2016) made this much clear. ${ }^{18}$ There is, though, a great deal of nuance to be considered within the sphere of public policy. Several theories have been suggested as to exactly why one might be held vicariously liable in increasingly extreme circumstances, which will now be discussed.

Firstly, arguably the most prominent theory justifying vicarious liability is that of the "deeper pockets" theory. ${ }^{19}$ This idea is rather straightforward: it posits

\footnotetext{
${ }_{17}$ Hornbeck, Four Approaches, 997-998.

18 [2016] UKSC 11, para 40.

19 Luskin, Caring About Corporate "Due Care", 304. Leiser, Respondeat Superior, 341. Brill, The Liability of an Employer, 2. Sykes, An Efficiency Analysis of Vicarious Liability, 172.
} 
that vicarious liability is claimed against 'masters' because they are often much better placed to compensate the victim of a servant's tort than the servant themselves. ${ }^{20}$ It must be noted that this theory is not considered as per se sufficient justification for the application of the doctrine ${ }^{21}$ - indeed, if this were (absurdly) the case, litigation would rarely be needed for vicarious liability. It does, however, fit well as a theory into the wider 'public policy' framework of the doctrine. Punishment of the servant is dealt with separately to vicarious liability cases but may not yield civil compensation for victims of the servant's tort. As such, it is only right that the party best placed to compensate for the actions of the servant - often the master - should offer compensation instead. As such, vicarious liability works to this end in that it compels the master to offer such compensation. The 'deeper pockets' rationale for vicarious liability is therefore understandable, though insufficient in itself as a reason for the expanding number of cases to which it is applied.

The second prominent justification for the doctrine is one based on fault. That a master has appointed a careless servant to a position of responsibility, or failed to supervise them appropriately, means that the master should therefore bear some of the burden of the servant's tort. ${ }^{22}$ Indeed, the aforementioned Australian case Deatons $v$ Flew - which has influenced English cases - the barmaid who committed the tort was being supervised and, subsequently, the bar was not charged as vicariously liable.23Though this justification is a sensible one, the implication for companies and other 'masters' is that they must ensure that their employees are constantly under authoritative monitoring from a superior in the company. In reality, how feasible is this? Businesses have to balance their human capital costs against the likelihood of a situation in which vicarious liability might arise. For example, in Mohamud $v$ WM Morrison Supermarkets Plc (2016), Morrisons was held vicariously liable for the intentional assault of a customer by a petrol station attendant. Following a verbal altercation in the kiosk, the attendant left the kiosk to

20 Brill, The Liability of an Employer, 2-3.

${ }^{21}$ Sykes, An Efficiency Analysis of Vicarious Liability, 172.

${ }^{22}$ Gilker, Vicarious Liability, 231.

23 [2001] UKHL 22, para 81. 
pursue the customer, whom he then assaulted. ${ }^{24}$ As such, is it really economically viable for Morrisons to constantly employ a supervisor in every petrol station to avoid the costs of a vicarious liability claim? It is understandable that courts have to uphold the social responsibility firms should have in society, which consists of - on a basic level - ensuring that their employees should follow the law. In many occupations, however, the risk of serious torts being committed within the 'scope of employment' should be incredibly small. On the other hand, consider a counterfactual in Mohamud briefly. If it was held that Morrisons was not vicariously liable for the assault of a customer by a petrol station attendant, it might encourage a laissez-faire attitude among firms to the actions of their employees. As such, this second justification is an essential axiom when making full case-by-case assessments of vicarious liability claims.

The third and final justification, closely linked with the second, is the deterrence idea. This idea suggests that vicarious liability has a net beneficial effect to society in that it encourages employers to be vigilant to their employees' behaviour and, subsequently, reduce the chances of tortious acts being committed by the employees to third parties. ${ }^{25}$ Being the most able to influence the decision of their employees during their course of employment, it should be the responsibility of employers to protect against future harm. The deterrence argument is an important consideration in the application of vicarious liability to specific cases. In holding a 'master' as vicariously liable for their servant's actions, it sends a message not only to the master/employer in question, but all employers, that they should be wary of their servants' actions. The demerits of this approach to vicarious liability were partially discussed in the previous paragraph. Though there are many realistic measures which employers can take to prevent their employees from committing torts, business costs have to be measured against the likelihood of a serious tort occurring within the course of employment. This might seem like a very cold approach but, as a business, profit margins are naturally a vital consideration.

\footnotetext{
24 2016] UKSC 11

25 Gilker, Vicarious Liability, 241-242.
} 
Following on from the third justification, should considerations about the 'type' of employer be made? With businesses, the profit motive means that it might not be in the best interests of businesses to try their best to protect against employees' torts, as the costs of protection might outweigh any compensatory payments from a rare vicarious liability claim. There is also the additional element regarding firms that as paid employees, it is not unreasonable to suggest that servants have considered the risk of losing their financial livelihood before - or during - committing a specific tort. How effective, then, is 'deterrence' as a motive against private businesses? The financial burden of deterring torts is their largest consideration. Voluntary organisations, however, do not have to bear the cost considerations of salaried employees. To increase supervision of servants in a voluntary organisation is not subject to the cost considerations of salaried employees. As such, the 'deterrent' motive for enforcing vicarious liability should theoretically be more effective in voluntary groups than in businesses, as voluntary groups do not have to bear employment costs and can, as such, modify the structure of their organisations at a smaller expense than that of private firms.

It is clear that vicarious liability has expanded considerably from its nineteenth-century grounding, but some of this expansion is perfectly understandable. Common law is a system designed in such a manner so that law can move with the times. Indeed, vicarious liability has been, as Lord Philips said in 'Christian Brothers', "on the move." ${ }^{26}$ But have the fundamental principles changed from the original essence of the doctrine? The 'scope of employment' test was the early basic foundation for vicarious liability, with the 'close connection' test seeking to provide a more expansive idea of 'scope', where actions were connected with opportunities presented by the authority of the employment. Recently, however, cases involving a vicarious liability claim have questioned the application of the doctrine to 'masters' beyond the form of a business constituting 'employer' and 'employees', including unincorporated associations, voluntary organisations, and the Catholic Church. To these groups, finding a 'close connection' is even more important,

26 [2012] UKSC 56. 
since the level of control that the 'masters' have over 'servants' who are not direct employees is not as clear prima facie as in a standard employment relationship.

Though vicarious liability has seen movement in the past two decades, two recent UK Supreme Court decisions might have brought this movement to a necessary halt. The judgments of WM Morrison Supermarkets plc $v$ Various Claimants (2020) ${ }^{27}$ and Barclays Bank plc $v$ Various Claimants (2020) ${ }^{28}$ were both given on the same day this year, holding that both WM Morrison Supermarkets plc and Barclays Bank plc were not vicariously liable for the torts of their 'servants.' In the former case, an internal auditor of Morrisons breached the Data Protection Act by sending the payroll data of over 100,000 Morrisons employees to three UK newspapers. The task he had originally been assigned to do was to share the payroll data with KPMG so that they could test their accuracy in an external audit. The Supreme Court held that the internal auditor was acting outside the scope of the tasks assigned to him, stating that the "opportunity" to commit the tort alone did not mean that Morrisons was vicariously liable. ${ }^{29}$ In the latter case, a doctor, as an independent contractor used by Barclays Bank plc, was tasked with carrying out the medical examinations in Barclays's application process. The doctor sexually abused some of the applicants during the medical examinations. The Supreme Court held that Barclays was not vicariously liable for the sexual abuse by the doctor on the basis that his relationship with Barclays was not close enough to be construed as employment, hence representing the modern importance of indirect master-servant relationships in vicarious liability cases today. 30

The significance of the UK Supreme Court's repudiating the continued expansion of vicarious liability is that the Supreme Court has now set definite limits of vicarious liability as a doctrine. There has been no change of the principles of vicarious liability which could warrant further expansion; indeed, 'scope of employment' seems as relevant a consideration now as it did in the

27 [2020] UKSC 12.

28 [2020] UKSC 13.

29 [2020] UKSC 12.

30 [2020] UKSC 13. 
nineteenth century. The 'close connection' test had to be made as a necessary consideration of how servants can abuse the authority handed to them by their masters. But the important principle of these decisions is that the courts of England will now be able to more clearly identify instances where vicarious liability should not be held. As such, it may help set the doctrine 'on ice' for a time, given that vicarious liability has expanded considerably since the nineteenth century and courts should be weary of 'overexpansion'. By bringing more 'master-servant' style relationships into the fold of vicarious liability, courts have the potential to inhibit judicial economy, even when public policy considerations are made. The situation in American common law stands at a similar point. Though American courts have been reluctant in applying the doctrine both in instances of intentional torts and when religious employers are involved, cases like Fearing $v$ Bucher 977 P.2d 1163 (Or. 1999) have put institutions of religious faith under greater scrutiny and suggests that the intentional torts exemption is being moved aside. ${ }^{31^{\star}} \mathrm{Gig}$ economy' jobs are set to be the new frontier of the vicarious liability doctrine. Though it is rare for firms hiring independent contractors to be held as vicariously liable unless there is a "high level of control", $3^{2}$ people who work for firms like Uber straddle the line between independent contractor and employee. As a result, US courts have expressed difficulty in providing an exact definition for 'master-servant' relationships in this grey area. 33

Anglo-American courts will undoubtedly continue to struggle defining the exact boundaries of vicarious liability, particularly with the increasing complexity of relationships which can be considered akin to employment. The largest recent developments have been about placing sexual abuse as being within the 'close connection' radius of vicarious liability tests. Religious employers have, as evidenced the judgments in Fearing $v$ Bucher and 'Christian Brothers', found themselves increasingly within reach of vicarious liability. Courts have recognised that "spiritual authority" offered by roles in a religious organisation can lead to these 'servants' committing torts,

${ }^{31}$ Sartor, The Implications of Fearing v. Bucher, 690-691. Patrick Hornbeck, Four Approaches, 1030.

32 Pager, Priest, Redeeming Globalization, 2490.

33 Vazquez, The Sharing Revolution, 650-651. 
subsequently meaning that religious organisations can equally be found vicariously liable as 'servants.' 34 Wilful torts and torts for the servant's benefit can now result in successful vicarious liability claims against masters, representing the largest contrasts in the doctrine between the nineteenth century and the present. Nevertheless, these aspects are still important considerations in cases today. In Mohamud, the fact that the servant told the third party not to return to the petrol station suggested that the servant was acting to benefit the master, ultimately contributing to the judgment that Morrisons was vicariously liable. 35 The two aforementioned 2020 UK Supreme Court decisions suggest that limits to the expansion of the doctrine are now being set - for the time being. In America, the blurring of the independent contractor exemption may lead to further expansion of vicarious liability. When deciding whether to expand the doctrine further, however, the courts should always remember why they are doing it. When holding organisations vicariously liable, courts must bear in mind the public policy implications of doing so. The actual tests for vicarious liability - the 'close connection' and 'scope of employment' tests - are of course vital to the outcomes of cases, but when judgments are on the fence, what really needs to be asked is whether the outcome of the case will actually deter future torts. The UK Supreme Court's recent judgments suggests that some 'limits of liability' may have indeed been set, but the proliferation of employers and 'servant' roles in the 'gig economy' means that those limits might yet be pushed further.

34 Hornbeck, Four Approaches, 1027-1028.

35 [2016] UKSC 11, para 47. 


\section{Bibliography}

\section{Primary Cases}

(1834) 6 C \& P 501.

(1862) 1 H \& C 526.

[1912] UKHL 606.

[2001] UKHL 22.

[2012] UKSC 56.

[2016] UKSC 11.

[2020] UKSC 12.

[2020] UKSC 13.

\section{Secondary Texts}

Brill, Ralph L. "The Liability of an Employer for the Wilful Torts of his Servants."

Chicago-Kent Law Review 45 (April 1968): 1-34.

Gilker, Paula. Vicarious Liability in Tort. Cambridge: Cambridge University Press, 2010.

Green, Gary S. “Respondeat Superior.” Encyclopaedia Britannica. Accessed 06 November 2020.

https://www.britannica.com/topic/respondeat-superior.

Hornbeck, Patrick. "Respondeat Superior Vicarious Liability for Clergy Sexual Abuse: Four Approaches." Buffalo Law Review 68, no. 4 (August 2020): 975-1036.

Leiser, Allan W. "Respondeat Superior - Intentional Torts as Being Within the Scope of Employment.” Marquette Law Review 40, no. 3 (Winter 1956-57): 337344.

Luskin, Robert. "Caring About Corporate "Due Care”: Why Criminal Respondeat Superior Liability Outreaches its Justification”. American Criminal Law Review 57 (Spring 2020): 303-330.

Pager, Sean A., Eric Priest. "Redeeming Globalization through Unfair Competition Law." Cardozo Law Review 41, no. 6 (2020): 2435-2520.

"Master and Servant: Liability of a Master for the Assaults of His Servant." California Law Review 17, no. 2 (January 1929): 185-187. 
Sartor, Michael J. "Respondeat Superior, Intentional Torts, and Clergy Sexual Misconduct: The Implications of Fearing v. Bucher." Washington and Lee Law Review 62, no. 2 (Spring 2005): 687-728.

Sykes, Alan O. "An Efficiency Analysis of Vicarious Liability under the Law of Agency." Yale Law Journal 91, no. 1 (1981): 168-206.

Vazquez, Cecilia G. "The Sharing Revolution: Changing Times Call for Clarifying Tort Liability." Louisiana Law Review 80, no. 2 (Winter 2020): 623-660. 